\title{
Advisor Based Modelling of the Effect of Rolling Resistance on Regenerative Braking in All-Electric Passenger Cars
}

\author{
Mehmet Akif KUNT* \\ Kutahya Dumlupınar University, Tavsanli Vocational School, Automotive Program, Tavsanli-Kutahya, TURKEY \\ mehmetakif.kunt@dpu.edu.tr
}

Received/Geliş: 07.08.2019

Accepted/Kabul: 24.09.2019

\begin{abstract}
In this study, the effect of rolling resistance change on regenerative braking was examined in an allelectric passenger car according to UDDS (Urban Dynamometer Driving Schedule) drive cycle. As the tires with high rolling resistance absorb the kinetic energy of the vehicle more than tires with low rolling resistance, regenerative braking gain is reduced. In the all-electric car model created using the ADVISOR vehicle simulation program state of charge (SOC) was found to be $87.1 \%$ in the car with low rolling resistance tires and SOC was $85.6 \%$ in the car with high rolling resistance for 1 drive cycle. In addition, regeneration recovery was also investigated due to road slope. As the road slope increased, the amount of recovery was reduced for both tires. While a recovery of $735.01 \mathrm{~kJ}$ was achieved in a tire with low rolling resistance, in a tire with high rolling resistance a recovery of $670.85 \mathrm{~kJ}$ was achieved at a $5 \%$ road slope.
\end{abstract}

Keywords: Regenerative braking, rolling resistance, ADVISOR, state of charge

\section{Elektrikli Binek Tipi Otomobillerde Yuvarlanma Direnci Değişiminin Rejeneratif Frenlemeye Etkisi}

\begin{abstract}
Öz: Bu çalı̧̧mada tümüyle elektrikli binek tipi bir otomobilde UDDS Urban Dynamometer Driving ScheduleKentsel Dinamometre Sürüş Programı) sürüş çevrimine göre yuvarlanma direnci değişiminin rejeneratif frenlemeye etkisi incelenmiştir. Yuvarlanma direnci yüksek lastiklerin düşük yuvarlanma direncine sahip lastiklere göre taşıtın kinetik enerjisini daha fazla absorbe etmesi sebebiyle rejeneratif frenleme kazanımı azalmıștır. ADVISOR taşıt simülasyon programı kullanılarak oluşturulan tümüyle elektrikli otomobil modelinde 1 sürüş çevrimi için düşük yuvarlanma direncine sahip lastik kullanan otomobilde State of Charge (SOC) \%87.1, yüksek yuvarlanma direncine sahip lastik kullanan otomobilde SOC değeri \%85.6 olarak bulunmuştur. Ayrıca yol eğimine bağlı olarak rejenerasyon geri kazanımı da araştırılmıştır. Yol eğiminin artmasıyla elde edilen geri kazanım miktarı her iki lastik için azalmıştır. \% 5 yol eğiminde yüksek yuvarlanma direncine sahip lastikte $670.85 \mathrm{~kJ}$ geri kazanım elde edilirken düşük yuvarlanma direncine sahip lastikte $735.01 \mathrm{~kJ}$ geri kazanım elde edilmiştir.
\end{abstract}

Anahtar kelimeler: Rejeneratif frenleme, yuvarlanma direnci, ADVISOR, şarj seviyesi

\section{Introduction}

Increases in the prices of fossil-based energy sources, uncertainties in their obtainment and environmental problems resulting from their use have increased the research of renewable energy sources by many automobile companies [1]. All-electric vehicles (EA) are called "zero-emission vehicles" because, theoretically, they do not emit any harmful gases [2]. However, there are many important problems with the spread of EAs that their range remains short in real driving conditions. Today, the factors that reduce the widespread use of EAs are; long charging time and short range of 
vehicles [3]. In order to prevent the negative effects of these factors on vehicle performance, it is essential to analyze and reduce energy losses well. The main energy losses in EAs are mainly from energy storage systems, electric motor, power train, slope resistance, weather resistance, rolling resistance and acceleration resistance. The most important factors in increasing the range of EAs are vehicle front projection area, battery energy density and rolling resistance coefficient [4]. In the course of driving, rolling resistance changes due to tire design characteristics, vertical load, air pressure, temperature and vehicle speed. Especially at low vehicle speeds, the rolling resistance of the vehicle is very important in terms of energy losses. Rolling resistance coefficients of the tires sold today vary between 0.007-0.014 [5]. This change affects the brake performance and the performance of the kinetic energy recovery system, which operates from time to time during braking. In order to make interpretations in a short time on the effect of rolling resistance on recovery, vehicle simulation programs are used. Designing and creating a simulation of an electric vehicle constitute the first stage of design and production. In order to realize these, simulation software is employed and this eases the production stage by making it shorter without any system performance [6].

In the literature, there are very few experimental-simulation studies showing the effect of rolling resistance on kinetic energy recovery performance. However, there are many recent studies on the modelling of EAs [7-16]. The essential common points of these studies that they are created in Matlab-Simulink software and ADVISOR software is used to obtain performance changes in all drive, power-train and energy storage systems in numerical values and graphs for different drive cycles. In this study, the change of regenerative braking performance of an all-electric passenger vehicle according to two different rolling resistance coefficients was investigated by using ADVISOR simulation program. In addition, the change in the state of charge (SOC) level is shown with a time-based graph.

\section{Modelling the Vehicle}

The ADVISOR simulation program is a software used to evaluate the behaviour of subsystems in a computer environment by using experimental data of the vehicle in Matlab Simulink. The user performs the modelling in two steps [17]. In the first step, with the help of the input screen (Figure 1), the measured, predicted or simulated components of the vehicle used and the vehicle data are determined, and in the second step, the desired drive cycle is selected and the speed-time schedule of the vehicle is created along the driving line (Figure 2). Then the model is executed and the outputs are shown on the result screen.

\subsection{Forces Affecting the Vehicle Movement}

The basic forces acting on the movement of the vehicle can be examined in two groups as the resistance forces that affect the vehicle against the direction of movement (slope resistance, inertial resistance, weather resistance, rolling resistance) and the driving forces that are generated by the engine to be transmitted to the wheels. Driving the vehicle in the forward direction, all these resistances must be overcome with the force generated by the engine. In equation (1) $F_{r}, F_{a}, F_{a c c}$, $F_{s t}$ represents rolling resistance, aerodynamic resistance, acceleration resistance and hill resistance, respectively.

$$
\begin{aligned}
& F_{t}=F_{r}+F_{a}+F_{a c c}+F_{s t} \\
& F_{r}=c_{r r o} m g+c_{r r 1} m g
\end{aligned}
$$




\section{Vehicle Input}
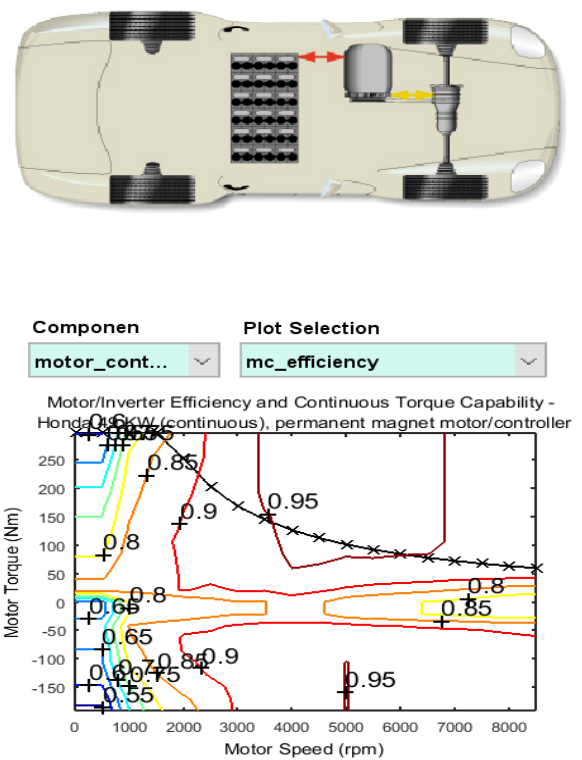

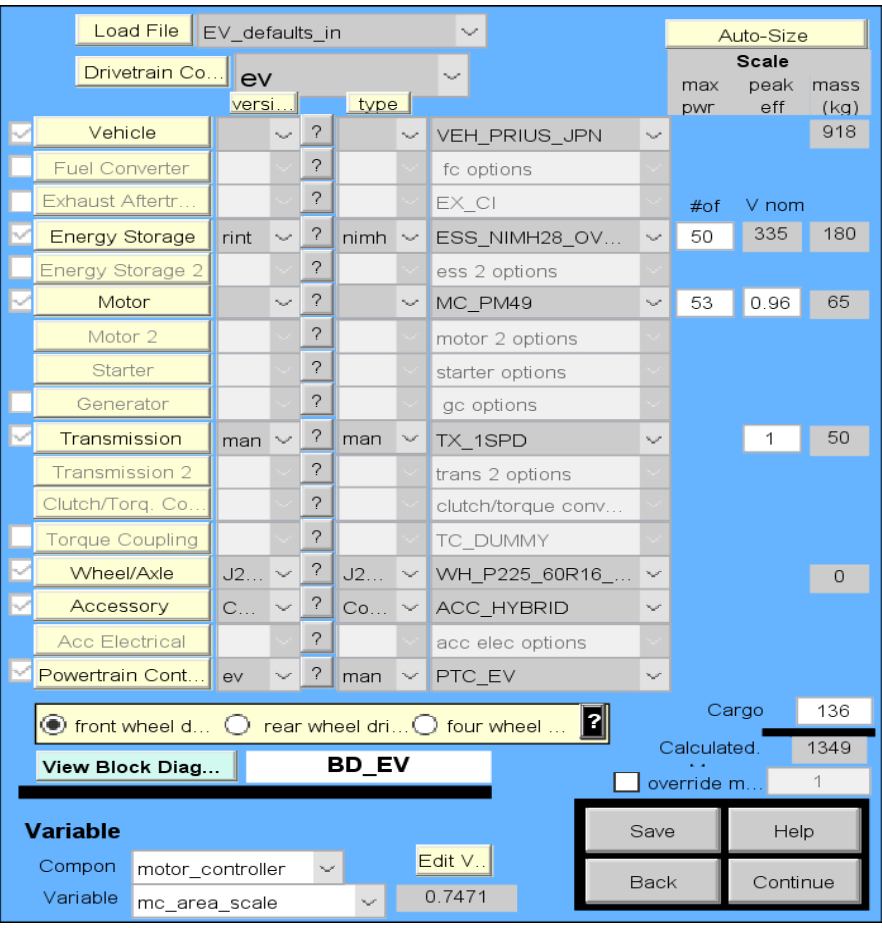

Figure 1. ADVISOR input screen
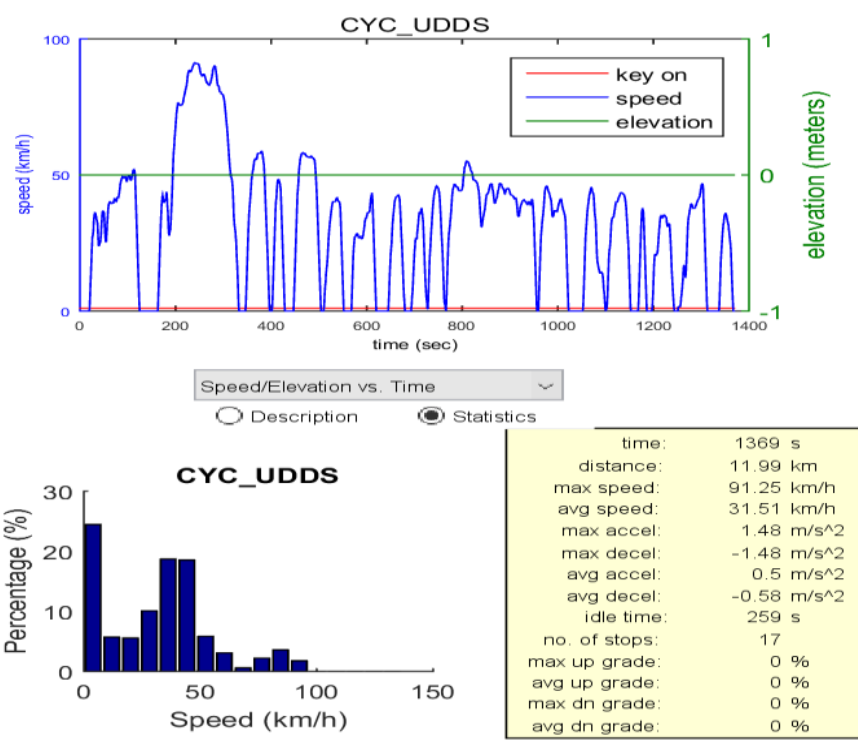

Figure 2. ADVISOR drive cycle selection page

$F_{a}=\frac{1}{2} \rho C_{D} A_{f} v^{2}$

$F_{a c c}=m M_{i} \frac{d v}{d t}$

$F_{s t}=m g \sin \alpha$

Maximum braking force in case of four-wheel braking:

$F_{b r \text { max }}=F_{b r}+F_{r}$ 
According to equation (6); maximum braking force is equal to the sum of the force generated by the brake system for deceleration $\left(F_{b r}\right)$ and rolling resistance $\left(F_{r}\right)$. Changes in rolling resistance change the load of the braking system for a constant braking force. In addition, the rolling resistance coefficient depends on many variables, but this resistance increases the resistances that must be overcome during the drive [18]. Regenerative braking is the process in which some of the kinetic energy stored by the vehicle due to its mass and speed is stored in the vehicle during deceleration or braking [19]. Electric and hybrid electric vehicles generally operate the traction motor as a generator to provide braking torque on the wheels and to recharge the traction batteries. Changes in rolling resistance before regenerative braking is activated affect the braking load and regenerative gain of the vehicle.

\begin{tabular}{|c|c|c|}
\hline$c_{\text {rro }}$ & $\begin{array}{l}\text { 1. Rolling resistance } \\
\text { coefficient }\end{array}$ & - \\
\hline$c_{r r 1}$ & $\begin{array}{l}\text { 1. Rolling resistance moving } \\
\text { coefficient }\end{array}$ & - \\
\hline$m$ & Vehicle mass & $\mathrm{kg}$ \\
\hline$g$ & Gravitational acceleration & $m / s^{2}$ \\
\hline$v$ & Vehicle speed & $\mathrm{m} / \mathrm{s}$ \\
\hline$\rho$ & Air density & $\mathrm{kg} / \mathrm{m}^{3}$ \\
\hline$C_{D}$ & $\begin{array}{l}\text { Aerodynamic friction } \\
\text { coefficient }\end{array}$ & - \\
\hline$A_{f}$ & Front cross-sectional area & $m^{2}$ \\
\hline$M_{i}$ & Inertia mass factor & - \\
\hline$d v$ & Vehicle speed change & $m / s^{2}$ \\
\hline $\begin{array}{c}\overline{d t} \\
\alpha\end{array}$ & $\begin{array}{l}\text { The inclination angle of the } \\
\text { road }\end{array}$ & $\circ$ \\
\hline
\end{tabular}

\section{Material and Methods}

Some of the mechanical energy generated by the vehicle during movement is consumed by the driving resistances. In this section, the effects of changes in rolling resistance on regenerative braking in the UDDS (Urban Dynamometer Driving Schedule) drive cycle and the energy lost in this energy transfer will be analyzed. The characteristics of the electric vehicle, vehicle battery and electric motor modelled in the simulation are given in Table 2 and Table 3. Analyses were conducted according to two different rolling resistance coefficients. Ni-Cad battery is preferred because it provides high discharge current and has higher energy density compared to lead-acid batteries.

Table 2: The technical features of the modelled electric vehicle.

\begin{tabular}{lll}
\hline Vehicle & & Other parameters \\
\hline Length of the vehicle & $4.3 \mathrm{~m}$ & \\
Vehicle width & $1.8 \mathrm{~m}$ & $\boldsymbol{\rho}=\mathbf{1 . 2 5} \mathbf{~ g ~} / \mathbf{m}^{\mathbf{3}}$ \\
Vehicle height & $1.4 \mathrm{~m}$ & \\
Total vehicle weight & $1344 \mathrm{~kg}$ & $\boldsymbol{g}=\mathbf{9 . 8 1} \mathbf{~ m} / \mathbf{s}^{\mathbf{2}}$ \\
Wheel radius (r) & $0.33 \mathrm{~m}$ & \\
Rolling resistance (High) & 0.012 & $\boldsymbol{C}_{\boldsymbol{d}}=\mathbf{0 . 3}$ \\
Rolling resistance (Low) & 0.008 & \\
Battery & Ni-Cad & \\
\hline
\end{tabular}




\begin{tabular}{lll}
\hline Minimum voltage & $4.57 \mathrm{~V}$ & $\boldsymbol{A}=\mathbf{1 . 7 4} \mathbf{~ m}^{\mathbf{2}}$ \\
Maximum voltage & $7.83 \mathrm{~V}$ & \\
Capacity & $28 \mathrm{Ah}$ & \\
Module mass (for 1 module) & $3.6 \mathrm{~kg}$ & \\
Number of modules & 50 & \\
\hline
\end{tabular}

Table 3. Technical values of electric motor.

\begin{tabular}{ll}
\hline Electric Motor & DC \\
\hline Minimum voltage & $60 \mathrm{~V}$ \\
Maximum current & $400 \mathrm{~A}$ \\
Mass & $60 \mathrm{~kg}$ \\
Inertia & $0.051 \mathrm{kgm}^{2}$ \\
\hline
\end{tabular}

\section{Results and Discussion}

Figure 3 shows the battery energy change graph for a tire with a high rolling resistance coefficient. During the movement of the tire with high rolling resistance according to the drive cycle, an average energy change of $4804.09 \mathrm{~kJ}$ occurred with regenerative drive. However, in the drive cycle without regeneration, more energy changes occurred in the batteries $(5396.31 \mathrm{~kJ})$. This indicates that $592.22 \mathrm{~kJ}$ more energy is consumed without recovery.

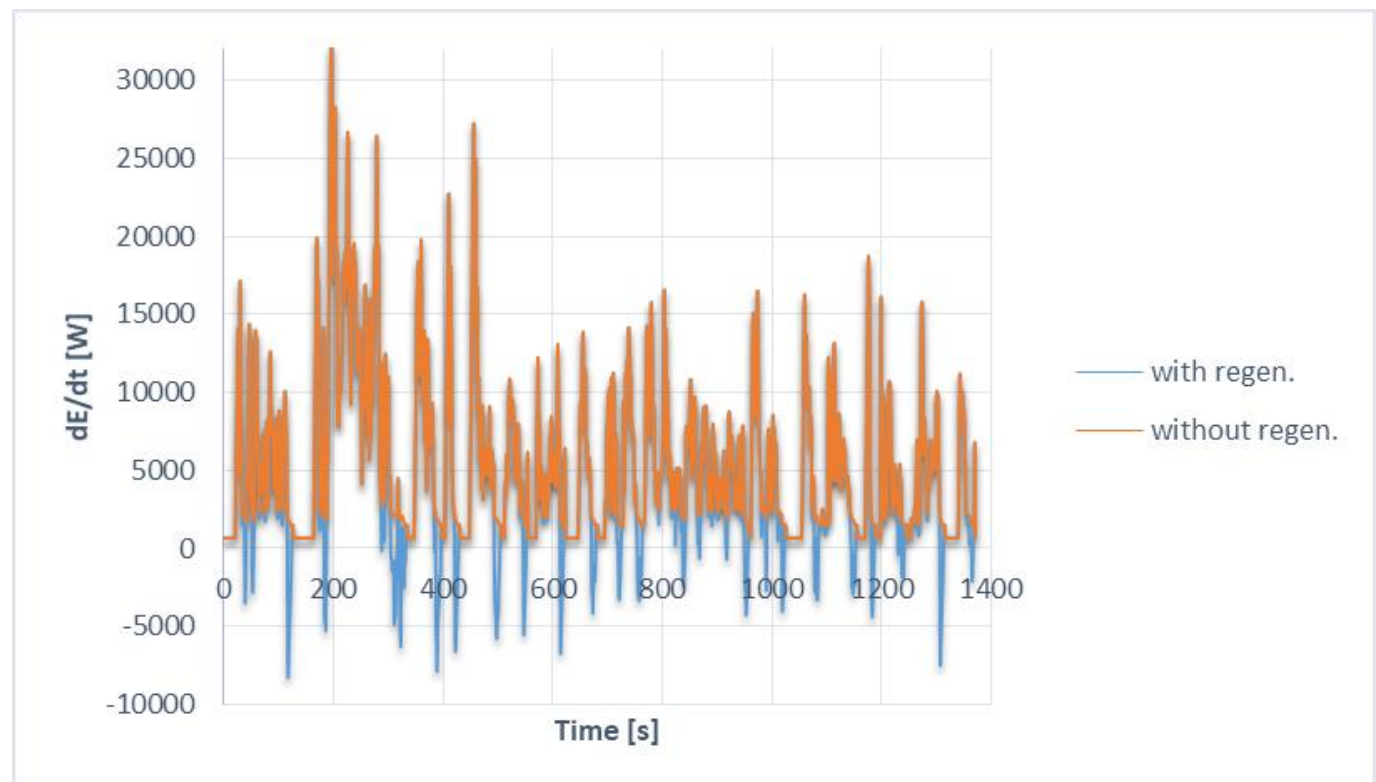

Figure 3. The battery energy change graph for a tire with a high rolling resistance coefficient.

Figure 4 shows the battery energy change graph for a tire with a low rolling resistance coefficient. The tire with low rolling resistance consumes less energy. During the movement of the tire with low rolling resistance according to the drive cycle, an average energy change of $4308.24 \mathrm{~kJ}$ occurred in the regenerated drive. However, in the drive cycle without regeneration, more energy changes occurred in the batteries $(4971.25 \mathrm{~kJ})$. This indicates that $663.01 \mathrm{~kJ}$ more energy is consumed without recovery. Comparing the low and high rolling resistance tires, a more efficient recovery performance was achieved with low rolling resistance tires with regeneration. 


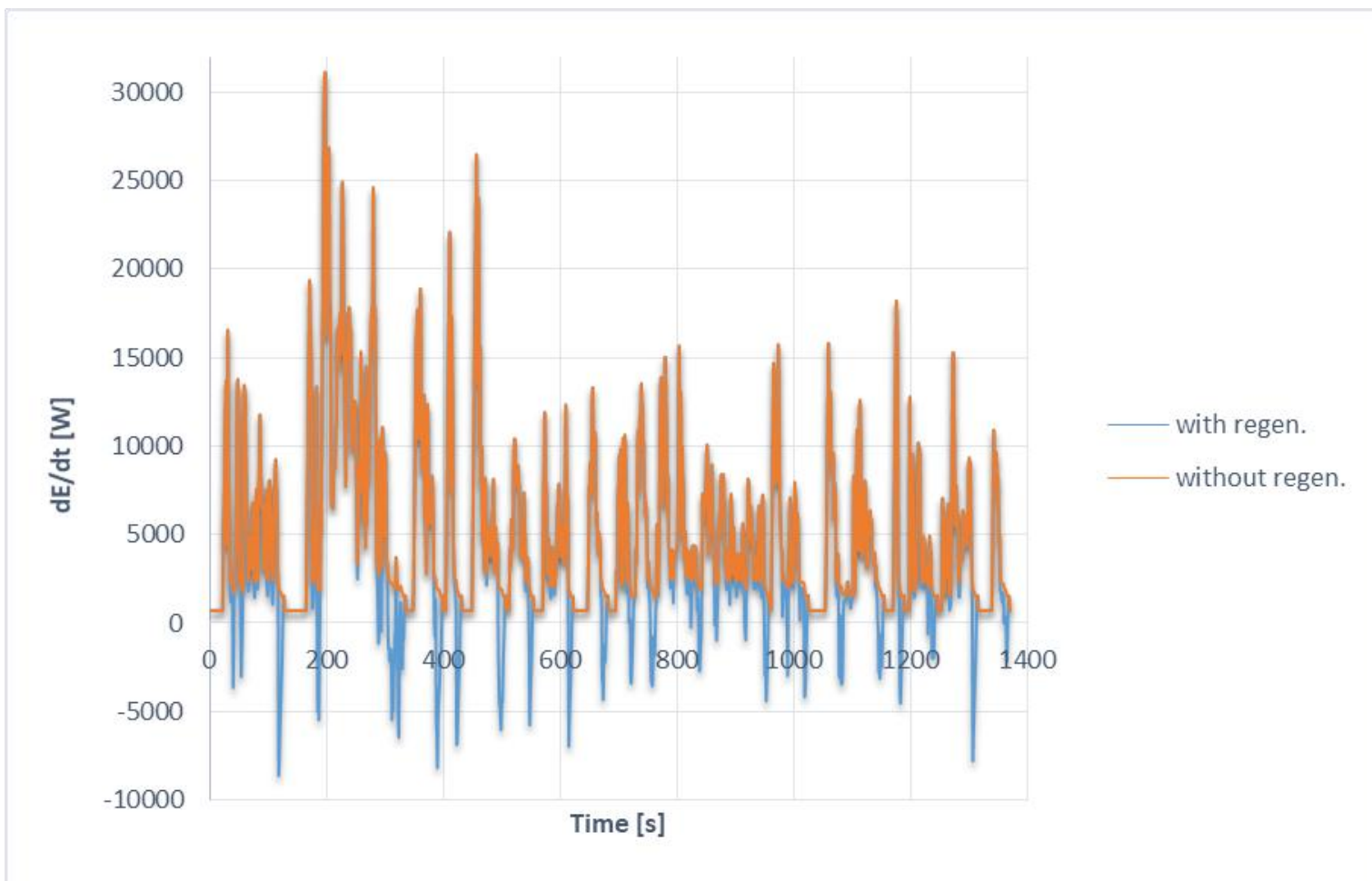

Figure 4. The battery energy change graph for a tire with a low rolling resistance coefficient.

Figure 5 shows a time-based battery energy change graph for tires with different rolling resistance with regeneration. Since the energy required to slow down the vehicle creates more rolling resistance on tires with high rolling resistance, it generates more energy flow during the wheel drive from the batteries of the electric vehicle. In addition, the recovery from regenerative braking had less effect on the batteries. The mentioned graph is prepared for the time interval 285-335 seconds at which the maximum speed reduction occurs.

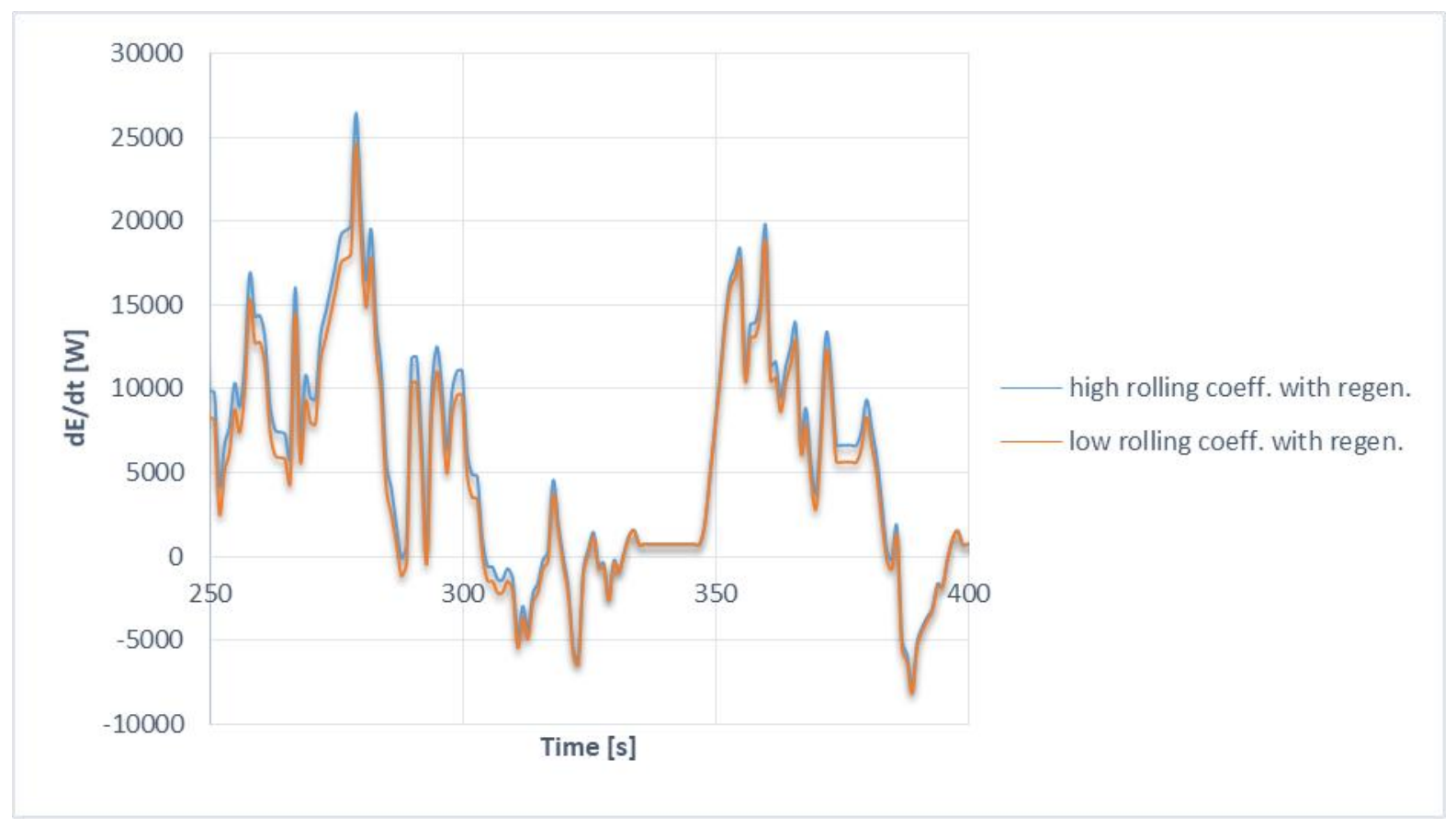

Figure 5. A time-based battery energy change graph for tires with different rolling resistance with regeneration. 
Figure 6 shows the time-based change of the vehicle battery charge. Regenerative braking energy remains low, as the braking energy required for the desired deceleration is reduced in the tire with high rolling resistance. As a result, the battery charge level of the vehicle using low rolling resistance tires in the drive cycle was higher. According to the fully charged battery drive cycle, the charge level of the vehicle with high rolling resistance was calculated as $85.6 \%$ and the charge level of the vehicle with low rolling resistance was calculated as $87.1 \%$.

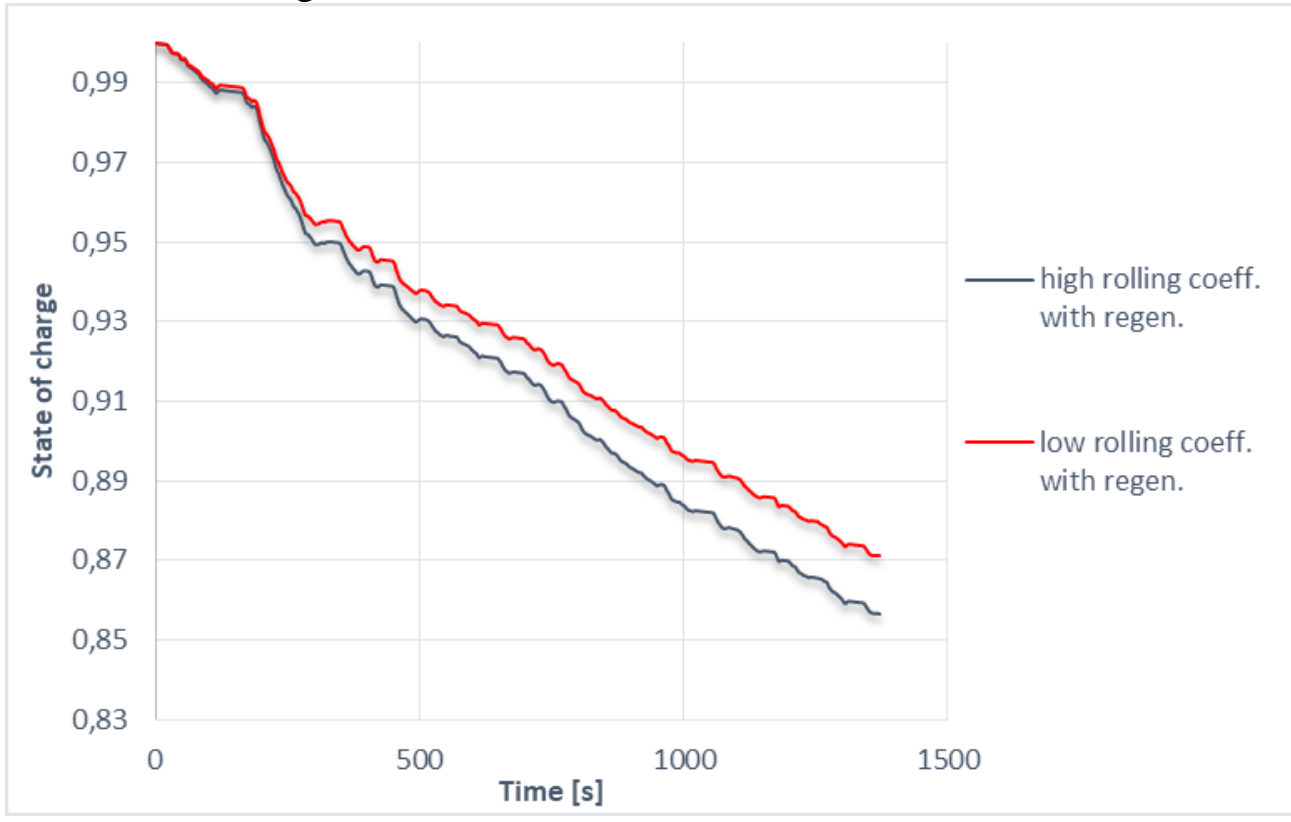

Figure 6. Time-based state of charge change (with Regeneration)

Figure 7 shows the variation of wheel brake losses over the time period 285-335 seconds at which the maximum speed reduction occurs in the drive cycle. According to this graph, the tire with high rolling resistance absorbs more vehicle energy due to the greater friction in the tread, shoulder and heel area of the tire during deceleration. For tires with low rolling resistance, the loss of energy due to the braking system is higher.

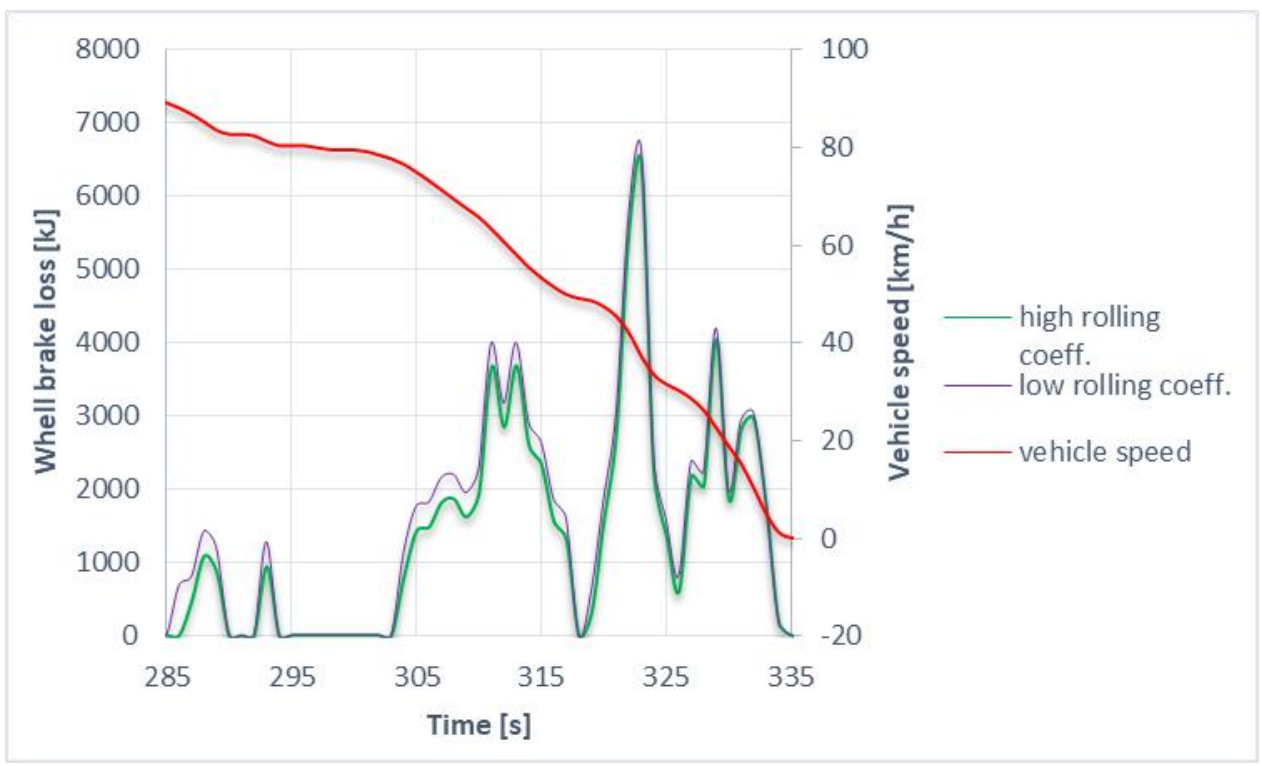

Figure 7. Time-based change of wheel brake loss 
Figure 8 shows the graph for braking with regeneration based on road slope during one drive cycle With the increase of the road slope, the effect of regenerative braking was decreased within the total force decelerating the vehicle. $1590.2 \mathrm{~kJ}$ recovery was achieved at a maximum slope of $0 \%$ in the drive cycle using high rolling resistance tires, while $1762.9 \mathrm{~kJ}$ recovery was achieved in the drive cycle using low rolling resistance tires. As the road slope increased, the amount of recovery was reduced for both tires. At 5\% road slope, $670.85 \mathrm{~kJ}$ recovery was achieved in the tire with high rolling resistance, while $735.01 \mathrm{~kJ}$ recovery was achieved in the tire with low rolling resistance.

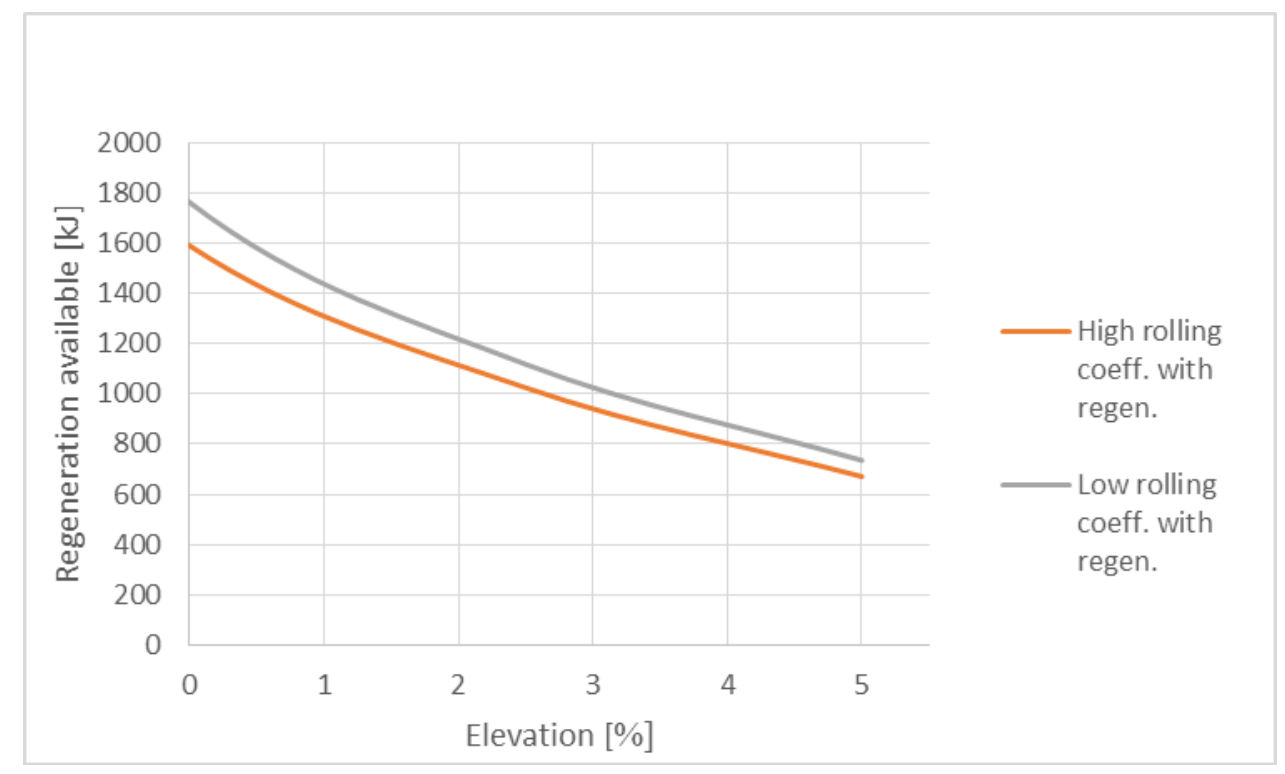

Figure 8. Regenerative braking gain due to road slope

\section{Conclusions}

More energy output occurred from the batteries, in the absence of a kinetic energy recovery system. It is seen that the tire with low rolling resistance coefficient consumes less energy than the batteries in the drive cycle. In the use of tires with high rolling resistance coefficient, an average of 4804.09 $\mathrm{kJ}$ of energy was consumed from the batteries, while vehicle batteries using low rolling resistance coefficient consumed an average of $4308.24 \mathrm{~kJ}$ of energy. Increased tire rolling resistance reduces the recovery energy that can be gained during regenerative braking during deceleration. The higher the kinetic energy recovery of the tire with the low rolling resistance coefficient, the higher the charge level of the battery during the driving cycle. According to the fully charged battery drive cycle, the charge level of the vehicle with high rolling resistance was calculated as $85.6 \%$ and the charge level of the vehicle with low rolling resistance was calculated as $87.1 \%$. By reducing the rolling resistance coefficients of the tires, kinetic energy recovery performance and the range of the all-electric vehicle can be increased. In order to achieve the target of this study, the performance of a vehicle with the characteristics of the vehicle designed for kinetic energy recovery under real driving conditions must be measured.

\section{References}

[1]. Keskin, A., Gürü, M., Altıparmak, D., Kunt, M.A., Production of Tall oil biodiesel and use of B80 as diesel fuel, Journal of Polytechnic, 2007, 10(4), 391-394.

[2]. Leitman, S., Brant, B. Build your own electric vehicle, The McGraw-Hill, Second Edition, USA, 2008.

[3]. [3] Huang Q., Li J., Chen Y., Control of electric vehicle, Urban Transport and Hybrid Vehicles, InTech, Chengdu, (2010). 
[4]. Yuan X., Li L., Gou H., Dong T., Energy and environmental impact of battery electric vehicle range in China, Applied Energy, 2015, 157, 75-84.

[5]. Trb special report 286 - Tires and passenger vehicle fuel economy. Transp ResBoard 2006.

[6]. Suvak H., Erşan K., Simulation of a photovoltaic panel supported real time hybrid electric vehicle. IEEE Conference Publications, Renewable Energy Research and Aplication (ICRERA) International Conference, Milwaukee, USA, 22 January 2015, 529-534.

[7]. Sorrentino M., Rizzo G., Sorrentino L., "A study aimed at assessing the potential impact of vehicle electrification on grid infrastructure and road-traffic green house emissions", Applied Energy, 2014, 120, 31-40.

[8]. Millo F., Rolando L., Fuso R., Mallamo F., "Real $\mathrm{CO}_{2}$ emissions benefits and end user's operating costs of a plug-in hybrid electric vehicle", Applied Energy, 2014, 114, 563-71.

[9]. Husain I, Islam MS. Design, modeling and simulation of an electric vehicle system, SAE, SAE Technical Paper No. 1999-01-1149, 1999.

[10]. Markel T, Brooker A, Hendricks T, Johnson V, Kelly K, Kramer B, et al., ADVISOR: a systems analysis tool for advanced vehicle modeling, Journal of Power Sources, 2002, 110, 255-66.

[11]. Xu JW, Zheng L., Simulation and analysis of series hybrid electric vehicle (SHEV) based on ADVISOR, International Conference on Measuring Technology and Mechatronics Automation, Changsha City, China, 13-14 March 2010, 1312-1321.

[12]. Kaloko B.S., Soebagio M.H.P., Purnomo M.H., Design and development of small electric vehicle using MATLAB/Simulink, International Journal of Computer Applications, 2011, 24, 19-23.

[13]. Schaltz E., "Electrical Vehicle Design and Modeling", Electric Vehicles - Modelling and Simulation, InTech, Shanghai, 2011.

[14]. Mapelli F.L., Tarsitano D., Modeling of Full Electric And Hybrid Electric Vehicles, New Generation of Electric Vehicles, INTECH Open Access Publisher, 2012.

[15]. Rashid M.I.M., Danial H., ADVISOR simulation and performance test of split plug-in hybrid electric vehicle conversion, Energy Procedia, 2017, 105, 1408-1413.

[16]. Suvak H., Erşan K., The simulation of a full electric vehicle using the city cycle, International Journal of Automotive Engineering and Technologies, 2016, 5(2), 38-46.

[17]. Brooker A., Haraldsson K., Hendricks T., Johnson V., Kelly K., Kramer B., Markel T., O'Keefe M., Sprik S., Wipke K., Zolot M., ADVISOR Documentation, National Renewable Energy Laboratory (NREL), April 2002.

[18]. Guzzela L., Sciarretta A., Vehicle Propulsion Systems, Springer, Second Edition, USA, 2007.

[19]. Erdem Y, Taci, M. S., Effect of regenerative braking and power analysis in electric vehicles, Journal of Current Researches on Engineering, Science and Technology, 2018, 4 (2), 75-88.

[20]. Xu G., Li W., Xu K., Song Z., An intelligent regenerative braking strategy for electric vehicles, Energies, 2011, 4 (9), 1461-1477. 